\title{
QUALITATIVE AND QUANTITATIVE ANALYSES OF SURFACE ALTERATIONS OF STONE TOOLS MADE OF RAW MATERIALS FROM THE CARPATHIAN BASIN
}

\author{
Antony Borel $^{1,2}$, Raphä̈l Deltombe ${ }^{3}$, Julie Marteau ${ }^{4}$, Philippe Moreau $^{3,5}$, MaXence Bigerelle ${ }^{3,5}$, \\ György LengYel ${ }^{6}$, Zsolt Mester $^{2,1}$ \\ Hungarian Archaeology Vol. 10 (2021), Issue 3, pp. 1-11. https://doi.org/10.36338/ha.2021.3.4
}

Wear analysis performed on archaeological stone tools from prehistory aims at characterizing their surface alterations in order to determine their functions and describe past human technical behaviors. However, the reliability and repeatability of the method is questioned and there is a major difficulty facing scientists analyzing wear, which is related to proposing quantified and repeatable analyses and interpretations of taphonomic and anthropogenic (related to manufacture and use) alterations of surfaces.

We propose the creation of an experimental reference collection of surface alterations focused primarily on selected stone types commonly found at Hungarian archaeological sites. This collection will allow the characterization of the topographic signatures of manufacture, use, and taphonomic processes. The qualitative (through observation using optical microscopy) and quantitative (through surface measurements using confocal microscopy) analyses will aim at examining: 1) the variability of surface alterations, 2) protocols that can allow the identification and characterization of surface topographic signatures, and 3) the appropriate metrological setups that will allow for each of the alteration processes to be differentiated.

We present here the results of the preliminary experiments, which involved flakes for bone and reed processing made of six different raw materials. It has been confirmed that use-wear can be identified on each one of them. Beyond the presentation of the first images from the reference collection we briefly present the future phases of the project.

Keywords: Prehistory, use-wear, lithic technology, surface analysis, topographic signature, Carpathian Basin

\section{INTRODUCTION}

How were these tools manufactured during prehistory? Were there different groups or even human species using different techniques to produce their tools? Could all stone flakes be used, and were they used? Were the tools held directly in the hand or were they hafted? Did they serve to cut, scrape, pierce, etc., skin, bone, or plants? These questions about prehistoric tools are fundamental to understanding the daily life of past humans, characterizing their relationship with the environment in which they lived, and identifying their technical adaptation.

For decades, these questions have deeply intrigued archaeologists, and they developed a discipline focused on the investigation of the methods and techniques used by past humans to produce and modify their tools, the typo-technological approach (e.g. BORDES 1961; TIXIER 1963). Stone knapping experiments were carried out quite early to examine the techniques used in Palaeolithic tool production (COUTIER 1929). Nevertheless, systematic research establishing criteria for the identification of production techniques of archaeological artifacts only started in the 1940s (BORDEs 1947). From the 1960s onward, scientific experimentation carried out by several scholars allowed the reconstruction of different debitage methods. How-

\footnotetext{
1 Histoire Naturelle de l'Homme Préhistorique (HNHP), Muséum national d'Histoire naturelle, CNRS, UPVD, 1 Rue René Panhard, 75013 Paris, France.

Institute of Archeological Sciences, Eötvös Loránd University, Múzeum krt. 4/B, 1088 Budapest, Hungary.

Université Polytechnique Hauts-de-France, LAMIH, CNRS, UMR 8201, 59313 Valenciennes, France.

4 Laboratoire Roberval, Sorbonne Université, Université de Technologie de Compiègne, Centre de Recherches de Royallieu, 60203 Compiègne, France.

INSA Hauts-de-France, 59313 Valenciennes, France

6 Department of Prehistory and Archaeology, University of Miskolc, 3515 Miskolc-Egyetemváros, Hungary
} 
Antony Borel et al. • Qualitative and Quantitative Analyses of Surface Alterations of Stone Tools
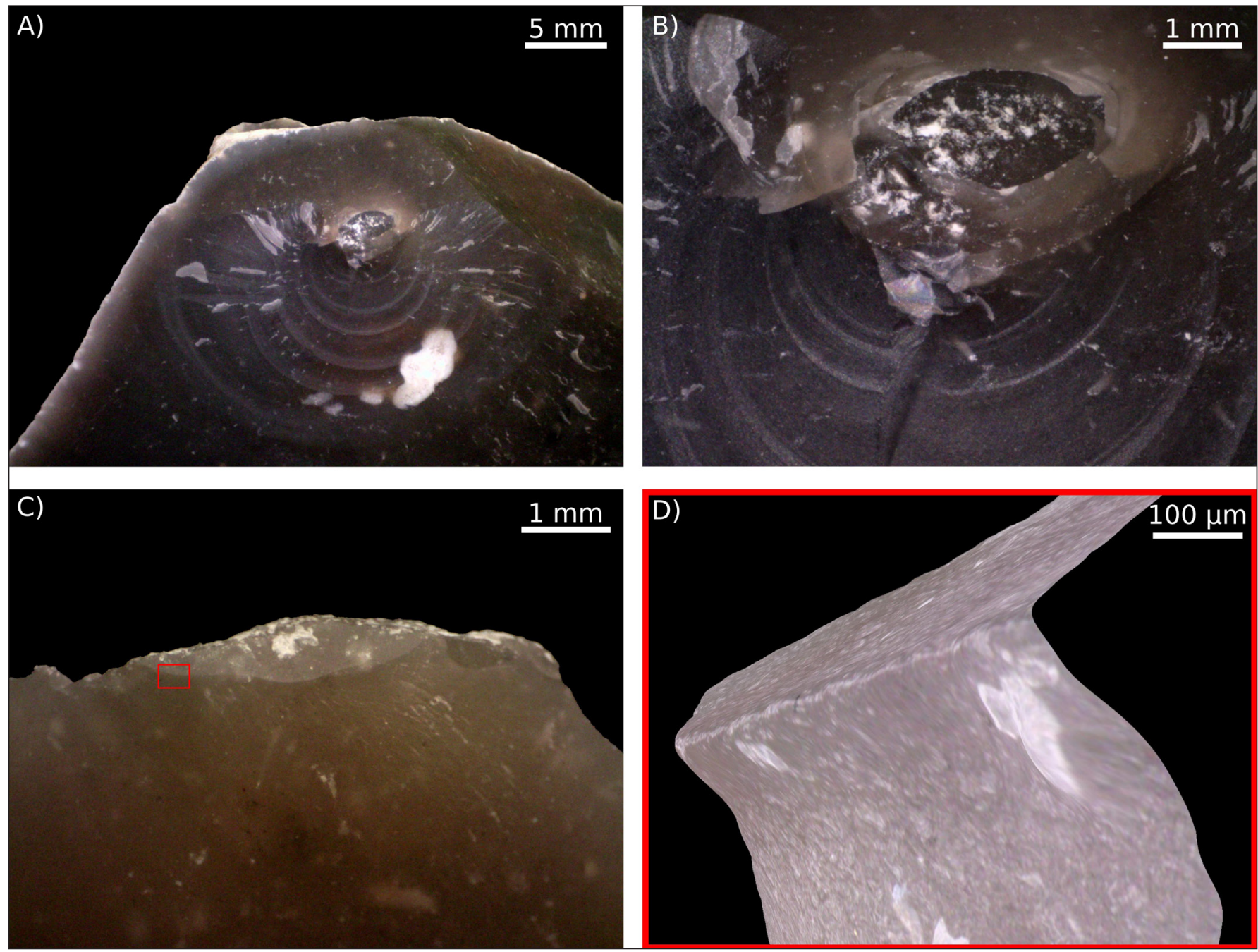

Fig. 1. Traces on flakes from $(A, B)$ stone hammer direct percussion and $(C, D)$ antler percussion. Residue of antler is visible on the butt in $C$. The red square on $C$ shows the location of the $3 D$ model presented in $D$. The scale given in $D$ is an approximation based on measurements taken on the 2D pictures used to build the model (with Helicon Focus software)

ever, only minor attention was paid to recording diagnostic features of different knapping techniques (see Inizan et al., 1999). General correlations between surface features and knapping techniques were suggested based on personal experience, but were questioned by other observations (TIXIER 1982). Controlled experiments about flake (and blade) production allowed for the discovery of correlations between morphological and metrical parameters of the blanks and the physical parameters of the knapping action, as well as the properties of the raw materials (Dibble \& Pelcin 1995; Dibble 1997; Andrefsky 2008; Eren et al. 2014; Lengyel \& Chu 2016). Nevertheless, detailed studies of the surface modifications resulting from the different knapping techniques (Fig. 1) are very rare (Pelegrin 2000; Driscoll \& García-Rojas 2014) and quantification of these traces for understanding their variability is absent for the most part.

The surfaces of the objects (stone tools in our case) are the elements most exposed to external contact, and therefore they are directly affected by every type of physical and chemical effect from the environment. Most of these effects (related to taphonomic or anthropogenic processes) modify surface topographies (BRown et al. 2018). Thus, the observation and characterization of surface topographic signatures on stone tools can provide reliable clues about the processes they have undergone. It is on the basis of this principle that traceology (also functional approach or wear analysis) was born and developed. This discipline focuses on the identification and characterization of the use of tools (e.g. Semenov 1964; KeELey 1980) and aims at identifying their function based on the description of striations, micro-fractures or scars, rounding, micropolishes, and residues (e.g. Borel et al. 2014; Stemp et al. 2015; see also Burroni et al. 2002; see Fig. 2). The translation 
Antony Borel et al. $・$ Qualitative and Quantitative Analyses of Surface Alterations of Stone Tools

from Russian into English of Semenov's comprehensive book (1964) about his pioneering research in the field marked the beginning of the internationalization of the discipline as applied to archaeological material. Since then, wear analysis has been widely developed, but many controversies and debates that are still relevant today (ODELL \& ODELL-VEREECKEN 1980; NewComer et al. 1986; Moss 1987; BAMForth 1988; Hurcombe 1988; Rots et al. 2006; ChAn et al. 2020) have arisen about the reliability and reproducibility of the method. While it is now established that wear analysis provides valuable clues to better understand how tools were used in the past and in what context, analyses and interpretations (that are mostly qualitative) are highly dependent on the understanding and experience of the observer and their related bias. Therefore, most debates have arisen from the fact that the identification of wear is mainly based on visual analogies between archaeological and experimental stone artifacts, and one of the main issues even today for microwear analysis is providing quantified analyses and assessable interpretations. This is why the development and/or application of quantitative methods that would complement the still fundamental qualitative approach is essential for the future of the discipline. The first attempts at applying quantitative methods for wear identification are actually not recent (e.g. SEMENOV 1970; Semenov \& ShChelinsky 1971; Dumont 1982; TomenchuK 1983; 1988; Grace et al. 1985; Beyries
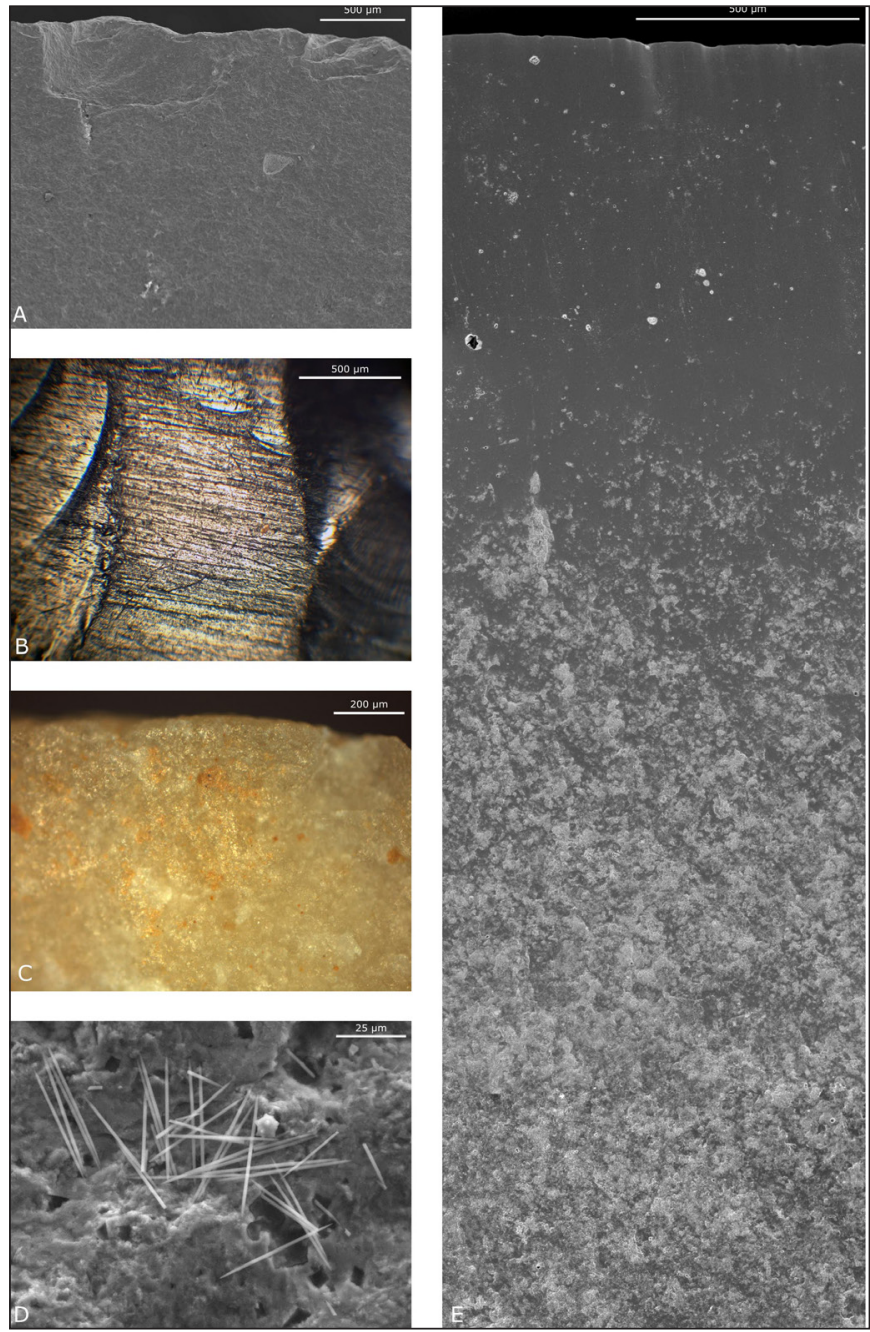

Fig. 2. Types of wear that make it possible to identify the function of archaeological stone tools. A) micro-fractures or scars, B) striations, C) rounding, D) residues, E) micropolish 1988). However, it has only been in the last two dec-

ades that attempts at wear (micropolish) quantification and the interest in methodological developments such as this have increased with the greater availability of surface acquisition technologies (non-contact technologies in particular). Focus variation microscopy and (laser) confocal microscopy in particular have provided very promising results. These two technologies have allowed for the identification of differences in surface textures between micropolishes from different contact materials (Evans \& Donahue 2008; Evans \& MaCDONALD 2011; IBÁÑEz et al. 2014; 2016; 2019; MACDONALD 2014; STEMP et al. 2018; Álvarez-FERnÁNDEZ et al. 2020; PICHON et al. 2021). In addition, an increasing number of recent studies have examined the effects of different variables involved in the formation of traces through controlled or even robotic experiments (KEY et al. 2015; 2018; Pfleging et al. 2015; 2019; Qiu 2016; Pfleging 2019; Calandra et al. 2020; Rodriguez et al. 2021). These seek to improve the reproducibility of analyses by testing the parameters of acquisition systems (e.g. CALANDRA et al. 2019b) or by proposing observation procedures (e.g. CALANDRA et al. 2019a).

Both typo-technological and functional approaches are well established as essential to determining the manufacturing techniques on the one hand and the processes of use the stone artifacts undergo on the other hand. However, as presented above, both face limitations in terms of accuracy and reproducibility. They also lack extensive experimental reference collections with clearly identified and quantified parameters that would allow them to provide models of characterization as well as classifications for the manufacturing techniques and the uses of archaeological stone tools. This is the case in particular concerning the raw materials used to make the stone tools found at archaeological sites in Hungary. 


\section{AIMS OF THE PROJECT}

The present project aims at: 1) creating a large experimental reference collection of stone tools produced using different techniques, employed for different activities, and modified by different taphonomical processes (i.e. accidental or natural post-depositional processes); and 2) describing, measuring and quantifying each topographic signature left on their surface. It will then be possible to: 3 ) provide reliable and reproducible wear classification models for the recognition of surface alteration processes for stone raw materials present at archaeological sites in Hungary.

The analysis of these data will make it possible to examine: 1) the variability of surface alterations for and between each tested taphonomic and anthropogenic process; 2) the establishment of a repeatable, replicable, and standardized protocol that can allow the identification and characterization of surface topographic signatures from manufacturing techniques, use, and taphonomical processes; and 3) the appropriate metrological geometric properties, scale, resolution, and statistics that allow for the determination of each manufacturing technique, use and taphonomical process.

The project is currently in its first stage and we present here the preliminary results of the ongoing experiment, which aims at evaluating how the selected raw materials react to use and if they are suitable for qualitative and quantitative wear analysis.

\section{MATERIAL AND METHODS}

Surface topographic signatures undoubtedly depend on the stone type from which the tools are made. Humans used numerous types of stone during prehistory, but this project focuses mainly on eight stone raw materials from Hungary and the surrounding areas (Fig. 3) commonly found in archaeological sites in Central Europe (Mester et al. 2012):

- radiolarite from the Bakony and Mecsek mountains (Hungary) and from the Western Carpathians (Slovakia);

- limnosilicite from the Tokaj, Mátra and Bükk mountains (Hungary);

- quartz-porphyry from Bükkszentlászló (Hungary);

- Krakow Jurassic flint (Southern Poland).

The pilot experiment presented here involved all of these raw materials except for the limnosilicite from the Mátra Mountains and the radiolarites from the Bakony Mountains and Western Carpathians. Only one experimenter (A.B.) performed all of the activities, which consisted of the use of 11 flakes for scraping or grooving dry bone for either 2,000, 4,000 , or 16,000 strokes, or sawing fresh reeds for 3,200 strokes (Table 1). Prior to the observations, the pieces were cleaned in an ultrasonic bath with neutral phosphate-free detergent $\left(5 \%\right.$ Derquim ${ }^{\circledR}$ LM 02) for fifteen minutes and then rinsed under running water. Microscopic documentation of the use-wear was done using a Zeiss AxioScope.A1 optical reflected light microscope equipped with EC epiplan-neofluar $5 \times$ (Numerical aperture (NA): 0.13 , working distance (WD): $15.8 \mathrm{~mm}), 10 \times(\mathrm{NA}$ : 0.25 , WD: $9.3 \mathrm{~mm}), 20 \times(\mathrm{NA}: 0.5$, WD: $2.1 \mathrm{~mm})$, and $50 \times$ (NA: 0.8 , WD: $0.58 \mathrm{~mm}$ ) objectives. When necessary, extended depth of field imaging (stacking) was performed using the Helicon Focus 7.6.4 Pro, and panoramic imaging (stitching) was performed using the Microsoft Image Composite Editor 2.0.3.0.

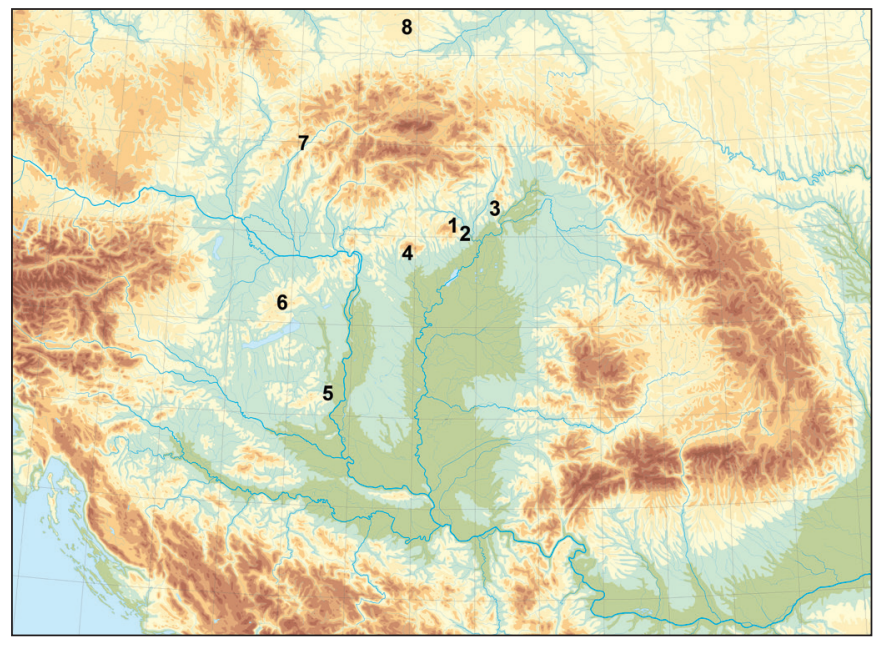

Fig. 3. Origins of raw materials selected for the experiments: quartz-porphyry (metarhyolite) (1) and limnosilicite (2) from the Bükk Mountains; limnosilicites from the Tokaj (3) and the

Mátra (4) mountains; radiolarite from the Mecsek (5) and the Bakony (6) mountains and the Western Carpathians (7); Krakow Jurassic flint (8) 
Antony Borel et al. • Qualitative and Quantitative Analyses of Surface Alterations of Stone Tools

Table 1: experiments performed within the framework of the first phase of the presented project

\begin{tabular}{lllllrc}
\hline Tool reference & Raw material & Origin & $\begin{array}{l}\text { Worked } \\
\text { material }\end{array}$ & Task & Duration & $\begin{array}{l}\text { No. of } \\
\text { Strokes* }\end{array}$ \\
\hline Wear2.0HU_01 & Limnosilicite & Bükk Mts., HU & Dry bone & Scraping & 2h 33min 20s & 16,000 \\
Wear2.0HU_02 & Jurassic flint & Krakow, Poland & Fresh reed & Sawing & 31min 17s & 3,200 \\
Wear2.0HU_03 & Limnosilicite & Tokaj Mts., HU & Fresh reed & Sawing & 34min 50s & 3,200 \\
Wear2.0HU_04 & Limnosilicite & Tokaj Mts., HU & Fresh reed & Sawing & $31 \mathrm{~min}$ & 3,200 \\
Wear2.0HU_05 & Limnosilicite & Tokaj Mts., HU & Dry bone & Scraping & 29min 43s & 4,000 \\
Wear2.0HU_06 & Limnosilicite & Tokaj Mts., HU & Fresh reed & Sawing & 26min 43s & 3,200 \\
Wear2.0HU_07 & Radiolarite & Mecsek Mts., HU & Fresh reed & Sawing & 26min 37s & 3,200 \\
Wear2.0HU_08 & Radiolarite & Mecsek Mts., HU & Dry bone & Grooving & 32min 51s & 4,000 \\
Wear2.0HU_09 & Quartz-porphyry & Bükkszentlászló, HU & Dry bone & Grooving & $30 \mathrm{~min}$ & 2,000 \\
Wear2.0HU_10 & Limnosilicite & Tokaj Mts., HU & Dry bone & Scraping & 2h 25min 57s & 16,000 \\
Wear2.0HU_11 & Quartz-porphyry & Bükkszentlászló, HU & Fresh reed & Sawing & 35min 35s & 3,200 \\
\hline
\end{tabular}

*For both scraping and sawing, one stroke corresponds to one back-and-forth movement.

\section{RESULTS}

The first results confirmed that traces (micropolish in particular) of bone and reed processing are detectable on each of the raw materials tested (Figs 4-10). However, traces due to reed sawing seem to develop more slowly on quartz-porphyry. Indeed, after 3,200 strokes, well-developed micropolishes are present on this raw material but less extended (Fig. 4) than, for example, on the Jurassic flint (Fig. 5) or on the radiolarite from the Mecsek Mountains (Fig. 6).

After 4,000 strokes, micropolish from bone processing already appears smooth on both limnosilicite from the Tokaj Mountains (Fig. 7) and radiolarite from the Mecsek Mountains (Fig. 8).
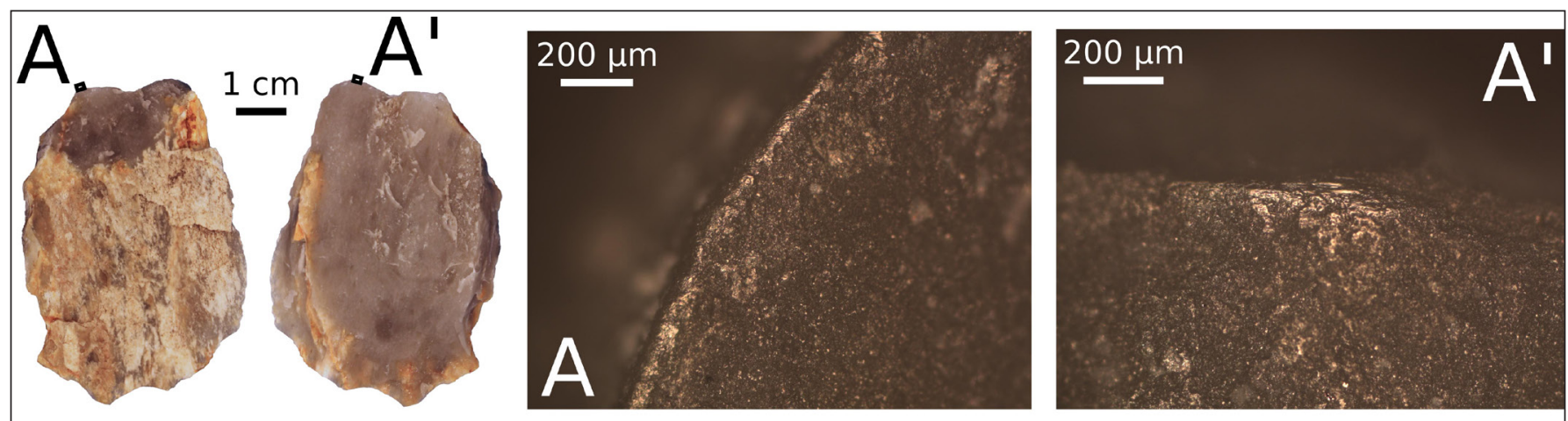

Fig. 4. Micropolish on an experimental stone tool (Wear2.0HU_11) made of quartz-porphyry (Bükkszentlászló, Hungary) and used to saw reed over $35 \mathrm{~min}$ (3,200 back-and-forth movements)

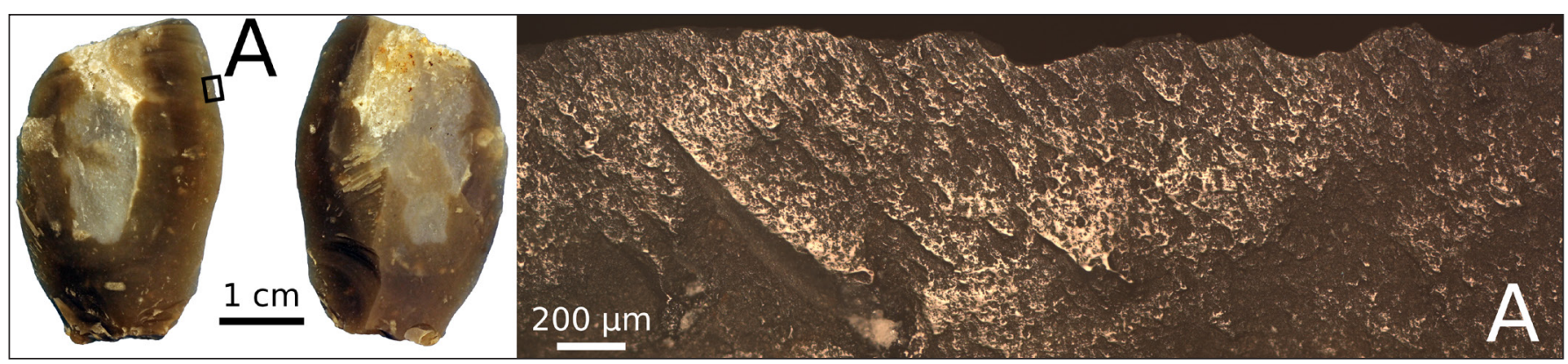

Fig. 5. Micropolish on an experimental stone tool (Wear2.0HU_02) made of Jurassic flint (Krakow, southern Poland) and used to saw reed over $31 \mathrm{~min}$ (3,200 back-and-forth movements) 
Antony Borel et al. $・$ Qualitative and Quantitative Analyses of Surface Alterations of Stone Tools

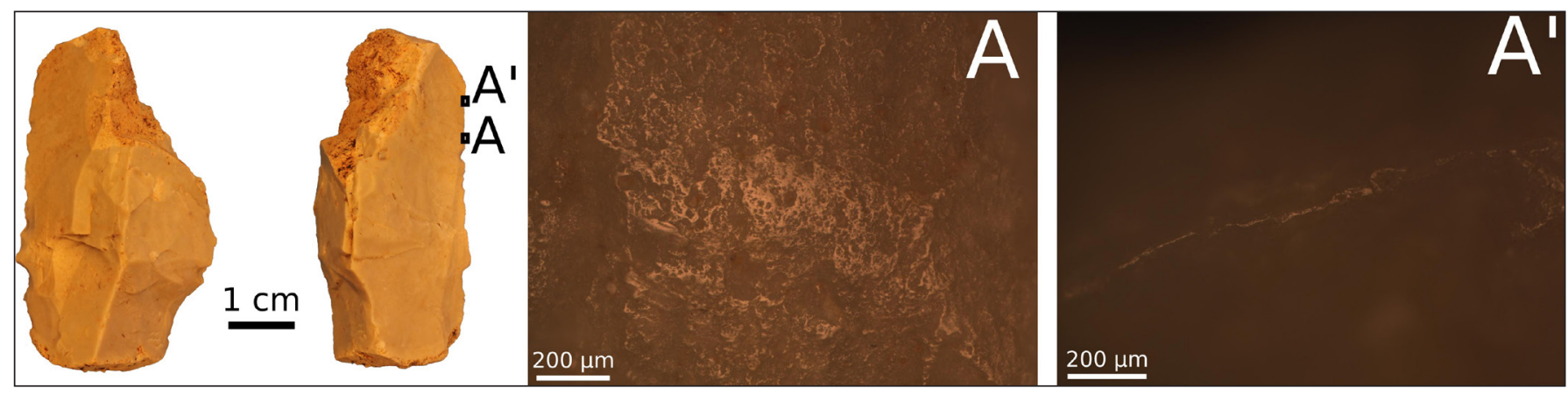

Fig. 6. Micropolish on an experimental stone tool (Wear2.0HU_07) made of radiolarite (Mecsek Mts., Hungary) and used to saw reed over $26 \mathrm{~min}$ (3,200 back-and-forth movements)

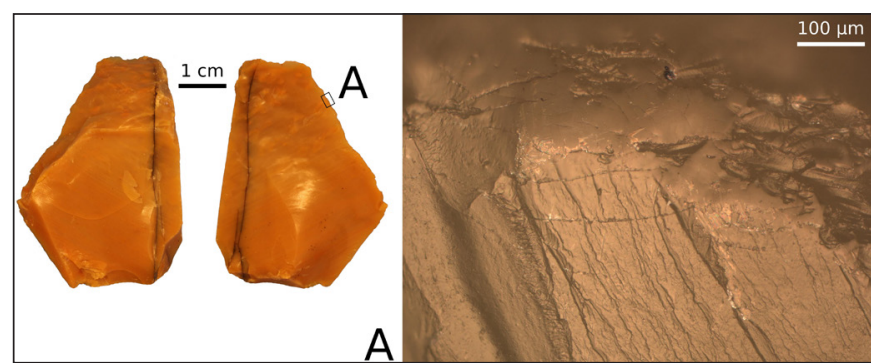

Fig. 7. Micropolish on an experimental stone tool (Wear2.0HU_05) made of limnosilicite (Tokaj Mts., Hungary) and used to scrape bone over $29 \mathrm{~min}$ (4,000 back-and-forth movements)

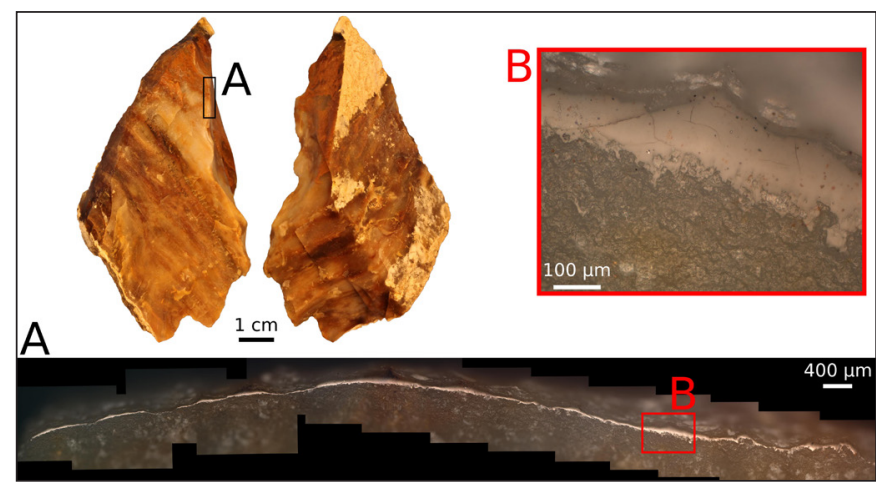

Fig. 9. Micropolish on an experimental stone tool (Wear2.0HU_01) made of limnosilicite (Bükk Mts., Hungary) and used to scrape bone over $2 \mathrm{~h} 33 \mathrm{~min}$ (16,000 back-andforth movements)

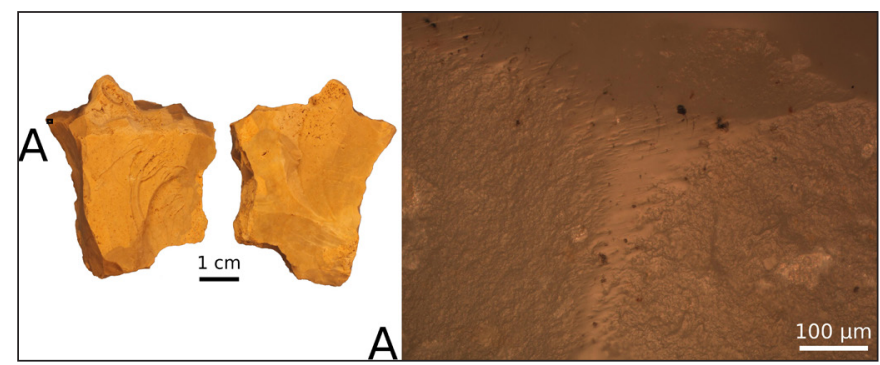

Fig. 8. Micropolish on an experimental stone tool (Wear2.0HU_08) made of radiolarite (Mecsek Mts., Hungary) and used to scrape bone over $32 \mathrm{~min}$ (4,000 back-and-forth movements)

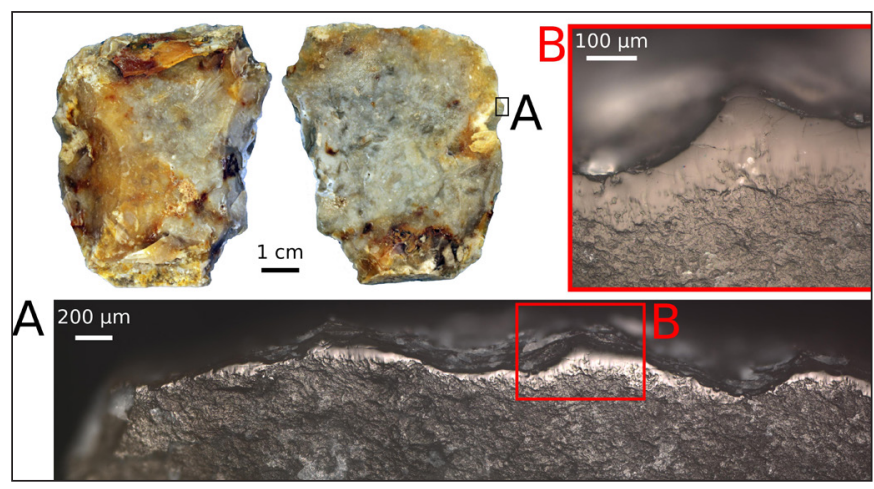

Fig. 10. Micropolish on an experimental stone tool (Wear2.0HU_10) made of limnosilicite (Tokaj Mts., Rátka site, Hungary) and used to scrape bone over $2 \mathrm{~h} 25 \mathrm{~min}$ (16,000 back-and-forth movements)

After 16,000 strokes, micropolish from bone processing is clearly visible on the used edge of the tools made of limnosilicite from the Bükk Mountains (Fig. 9) and from the Rátka site of the Tokaj Mountains (Fig. 10). This micropolish is very smooth in appearance and extends to approximately $100 \mu \mathrm{m}$ on the surface next to the edge on both tools.

\section{PRIMARY CONCLUSIONS AND PERSPECTIVES}

This first experiment made it possible to confirm that micropolishes from use can be observed by optical microscopy on each of the selected materials from the Carpathian Basin. To our knowledge, most of the raw materials from these specific regions had never been tested before for wear analysis.

Continuing on, extensive experiments are currently in progress. Most activities are being performed without any limitations in terms of the number of individuals performing the tasks, but the effects of the 
individuals on the results will be evaluated by a controlled experiment using a tribometer. Sequential experiments (OlLÉ \& VERGĖs 2014) involving two types of motions (i.e. sawing and scraping) and four contact materials (i.e. bone, antler, wood, and reed) are being performed. We first intend to quantify differences between these categories of contact materials, but the variability within each of these categories will also be evaluated. Indeed, fresh or dry reed as well as dry or soaked antler, for example, are likely to produce different wear patterns and thus different topographic signatures.

The pilot experiment presented here has also made it possible to test different technologies and select the most suitable for the measurement of the surfaces of these stone tools. The topography of each surface will thus be documented and measured microscopically using laser confocal microscopy (e.g. Evans \& MACDONALd 2011; Stemp et al. 2018). The comparison of the measured topographies before and after use will make it possible to quantify the variability of the topographic signatures depending on motion and contact material as well as to examine the evolution of these signatures through cycles (i.e. number of strokes) of use.

Experimental manufacture of stone artifacts will also be performed by three different knappers who will produce stone artifacts using direct percussion with hard stone, soft stone, wood and antler. Each artifact will be observed in detail macroscopically and at low magnification under a binocular microscope. Surface topographic signature acquisition and measurements will be carried out on a selection of artifacts depending on the actual variability of surface alterations observed during the macroscopic analysis. In addition, in order to avoid misidentification of manufacturing techniques and types of use based on topographic signatures, surface alterations due to natural or accidental processes will be also investigated. Two taphonomic experiments, trampling and sediment friction, will be performed.

The description and measurement of the aforementioned topographic signatures of manufacture, use and taphonomic processes and, above all, the evaluation of their variability, will first make it possible to differentiate categories of contact materials. This project will remain open-ended, since the continuous addition of new experiments and surface topography data will progressively increase the reliability of future models and later will likely provide clues about more specific contact material types and activities. Both the new experimental collection and the statistical models based on surface measurements will provide new comparative data to interpret archaeological stone tools found at sites in the Carpathian Basin. The experimental collection is stored and curated at the laboratory of archaeometry of the Institute of Archaeological Sciences of Eötvös Loránd University (Budapest, Hungary). Possible alteration or variation of surface topographies, for example due to handling or contact with storage surfaces, will be documented through control measurements carried out on the artifacts on a regular basis.

\section{ACKNOWLEDGEMENTS}

The raw materials used in the experiments were acquired within the framework of the "Lithic Resource Management Dynamics from the Middle Palaeolithic to the Middle Neolithic in Northern Hungary" project financed by the NRDI Fund (grant no. K 124334) of Hungary. The analysis presented in this paper was performed in the framework of the "Qualitative and Quantitative Analyses of Surface Alterations of Stone Tools: Creation of a Digital and Physical Reference Collection for the Characterization of Traces of Manufacture and Use on Stone Raw Materials from Hungary" project financed by the NRDI Fund (grant no. K 132857) of Hungary. The microscope was provided by the USZT KMOP-4.2.1/B-10-2011-0002: "Interdisciplinary and Innovative Research Approaches and Development of Infrastructural Background for Industrial Cooperation and Introduction of New Educational Technologies at Eötvös Loránd University (Budapest, Hungary)" project. We would like to acknowledge GDR SurfTopo (CNRS GDR 2077) for providing an inspiring environment for surface topography research. We are also grateful to Istvánné Dósa and the hunters and butchers who provided us with the bone, antler, and hide materials used in our experiments. 
Antony Borel et al. $\bullet$ Qualitative and Quantitative Analyses of Surface Alterations of Stone Tools

\section{REFERENCES}

Álvarez-Fernández, A., García-González, R., Márquez, B., Carretero, J. M. \& Arsuaga, J. L. (2020). Butchering or wood? A LSCM analysis to distinguish use-wear on stone tools. Journal of Archaeological Science: Reports 31, 102377. https://doi.org/10.1016/j.jasrep.2020.102377

Andrefsky, W. Jr. (2008). Lithic Technology: Measures of production, use, and curation. New York: Cambridge University Press.

Bamforth, D.B. (1988). Investigating microwear polishes with blind tests: The institute results in context. Journal of Archaeological Science 15, 11-23. https://doi.org/10.1016/0305-4403(88)90015-5

Beyries, S. (1988). Industries Lithiques: tracéologie et technologie. Volume 1: Aspects archéologiques. Centre de Recherches Archéologiques du CNRS. BAR International Series 411. Oxford: Archaeopress.

Bordes, F. (1947). Etude comparative des différentes techniques de débitage et de la typologie du Paléolithique ancien et moyen. L'Anthropologie 51, 1-29.

Bordes, F. (1961). Typologie du Paléolithique ancien et moyen. Institut de Préhistoire de l'Université de Bordeaux.

Borel, A., Ollé, A., Vergès, J. M. \& Sala, R. (2014). Scanning Electron and Optical Light Microscopy: two complementary approaches for the understanding and interpretation of usewear and residues on stone tools. Journal of Archaeological Science 48, 46-59. https://doi.org/10/gd6cng

Brown, C. A., Hansen, H. N., Jiang, X. J., Blateyron, F., Berglund, J., Senin, N., Bartkowiak, T., Dixon, B., Le Goïc, G., Quinsat, Y., Stemp, W. J., Thompson, M. K., Ungar, P. S. \& Zahouani, E. H. (2018). Multiscale analyses and characterizations of surface topographies. CIRP Annals 67, 839-862. https://doi. org/10.1016/j.cirp.2018.06.001

Burroni, D., Donahue, R. E., Pollard, A. M. \& Mussi, M. (2002). The surface alteration features of flint artefacts as a record of environmental processes. Journal of Archaeological Science 29, 1277-1287. https:// doi.org/10.1006/jasc.2001.0771

Calandra, I., Schunk, L., Rodriguez, A., Gneisinger, W., Pedergnana, A., Paixao, E., Pereira, T., Iovita, R. \& Marreiros, J. (2019a). Back to the edge: relative coordinate system for use-wear analysis. Archaeological and Anthropological Sciences. https://doi.org/10.1007/s12520-019-00801-y

Calandra, I., Schunk, L., Bob, K., Gneisinger, W., Pedergnana, A., Paixao, E., Hildebrandt, A. \& Marreiros, J. (2019b). The effect of numerical aperture on quantitative use-wear studies and its implication on reproducibility. Scientific Reports 9, 1-10. https://doi.org/10.1038/s41598-019-42713-w

Calandra, I., Gneisinger, W. \& Marreiros, J. (2020). A versatile mechanized setup for controlled experiments in archeology. STAR: Science \& Technology of Archaeological Research 6 (1), 30-40. https://doi.org/10.1 $\underline{080 / 20548923.2020 .1757899}$

Chan, B., Gibaja, J. F., García-Díaz, V., Hoggard, C. S., Mazzucco, N., Rowland, J. T. \& Gijn, A. V. (2020). Towards an understanding of retouch flakes: A use-wear blind test on knapped stone microdebitage. PLoS ONE 15, e0243101. https://doi.org/10.1371/journal.pone.0243101 
Antony Borel et al. $\bullet$ Qualitative and Quantitative Analyses of Surface Alterations of Stone Tools

Coutier, L. (1929). Expériences de taille pour rechercher les anciennes techniques paléolithiques. Bulletin de la Société préhistorique française 26, 172-174.

Dibble, H. L. (1997). Platform variability and flake morphology: A comparison of experimental and archaeological data and implications for interpreting Prehistoric lithic technological strategies. Lithic Technology 22, 150-170. https://doi.org/10.1080/01977261.1997.11754540

Dibble, H. L. \& Pelcin, A. (1995). The effect of hammer mass and velocity on flake mass. Journal of Archaeological Science 22, 429-439. https://doi.org/10.1006/jasc.1995.0042

Driscoll, K. \& García-Rojas, M. (2014). Their lips are sealed: identifying hard stone, soft stone, and antler hammer direct percussion in Palaeolithic prismatic blade production. Journal of Archaeological Science 47, 134-141. https://doi.org/10.1016/j.jas.2014.04.008

Dumont, J. (1982). The quantification of microwear traces: ANew use for interferometry. World Archaeology $14,206-217$.

Eren, M. I., Roos, C. I., Story, B. A., Cramon-Taubadel, N. von \& Lycett, S. J. (2014). The role of raw material differences in stone tool shape variation: an experimental assessment. Journal of Archaeological Science 49, 472-487. https://doi.org/10.1016/j.jas.2014.05.034

Evans, A. A. \& Donahue, R. E. (2008). Laser scanning confocal microscopy: a potential technique for the study of lithic microwear. Journal of Archaeological Science 35, 2223-2230. https://doi.org/10.1016/j. jas.2008.02.006

Evans, A. A. \& Macdonald, D. (2011). Using metrology in early prehistoric stone tool research: further work and a brief instrument comparison. Scanning 33, 294-303. https://doi.org/10.1002/sca.20272

Grace, R., Graham, I. D. G. \& Newcomer, M. H. (1985). The quantification of microwear polishes. World Archaeology 17, 112-120.

Hurcombe, L. (1988). Some criticisms and suggestions in response to Newcomer et al. (1986). Journal of Archaeological Science 15, 1-10. https://doi.org/10.1016/0305-4403(88)90014-3

Ibáñez, J. J., González-Urquijo, J. E. \& Gibaja, J. (2014). Discriminating wild vs. domestic cereal harvesting micropolish through laser confocal microscopy. Journal of Archaeological Science, Lithic Microwear Method: Standardisation, Calibration and Innovation 48, 96-103. https://doi.org/10.1016/j.jas.2013.10.012

Ibáñez, J. J., Anderson, P. C., González-Urquijo, J. \& Gibaja, J. (2016). Cereal cultivation and domestication as shown by microtexture analysis of sickle gloss through confocal microscopy. Journal of Archaeological Science 73, 62-81. https://doi.org/10.1016/j.jas.2016.07.011

Ibáñez, J. J., Lazuen, T. \& González-Urquijo, J. (2019). Identifying experimental tool use through confocal microscopy. Journal of Archaeological Method and Theory 26, 1176-1215. https://doi.org/10.1007/s10816$\underline{018-9408-9}$

Inizan, M.-L., Reduron-Ballinger, M., Roche, H. \& Tixier, J. (eds) (1999). Technology and Terminology of Knapped Stone. Préhistoire de la pierre taillée. Nanterre: CREP. 
Antony Borel et al. $\bullet$ Qualitative and Quantitative Analyses of Surface Alterations of Stone Tools

Keeley, L. H. (1980). Experimental Determination of Stone Tool Uses: A microwear analysis. Chicago: University of Chicago Press.

Key, A., Fisch, M. R. \& Eren, M. I. (2018). Early stage blunting causes rapid reductions in stone tool performance. Journal of Archaeological Science 91, 1-11. https://doi.org/10.1016/j.jas.2018.01.003

Key, A. J. M., Stemp, W. J., Morozov, M., Proffitt, T. \& Torre, I. de la (2015). Is loading a significantly influential factor in the development of lithic microwear? an experimental test using LSCM on basalt from Olduvai Gorge. Journal of Archaeological Method and Theory 22, 1193-1214. https://doi.org/10.1007/ $\underline{\mathrm{s} 10816-014-9224-9}$

Lengyel, G. \& Chu, W. (2016). Long thin blade production and Late Gravettian hunter-gatherer mobility in Eastern Central Europe. Quaternary International, The Lithic Issues of the Gravettian 406, 166-173. https://doi.org/10.1016/j.quaint.2016.01.020

Macdonald, D. A. (2014). The application of focus variation microscopy for lithic use-wear quantification. Journal of Archaeological Science, Lithic Microwear Method: Standardisation, Calibration and Innovation 48, 26-33. https://doi.org/10.1016/j.jas.2013.10.003

Mester, Z., Faragó, N. \& Lengyel, G. (2012). The lithic raw material sources and interregional human contacts in the northern Carpathian regions: a research program. Anthropologie 50, 275-293.

Moss, E. H. (1987). A review of "Investigating microwear polishes with blind tests." Journal of Archaeological Science 14, 473-481. https://doi.org/10.1016/0305-4403(87)90033-1

Newcomer, M., Grace, R. \& Unger-Hamilton, R. (1986). Investigating microwear polishes with blind tests. Journal of Archaeological Science 13, 203-217. https://doi.org/10.1016/0305-4403(86)90059-2

Odell, G. H. \& Odell-Vereecken, F. (1980). Verifying the reliability of lithic use-wear assessments by "blind tests": the low-power approach. Journal of Field Archaeology 7, 87-120. https://doi.org/10.2307/529584

Ollé, A. \& Vergès, J. M. (2014). The use of sequential experiments and SEM in documenting stone tool microwear. Journal of Archaeological Science 48, 60-72. https://doi.org/10/gd6c46

Pelegrin, J. (2000). Les techniques de débitage laminaire au Tardiglaciaire: critères de diagnose et quelques réflexions. In: L'Europe Centrale et Septentrionale Au Tardiglaciaire. Actes de La Table-Ronde de Nemours, 13-16 Mai 1997, Mémoires Du Musée de Préhistoire d'Île de France (pp. 73-86). Nemours: APRAIF.

Pfleging, J. (2019). On the Foundations of Robotic Use-wear Analysis: Improving Archaeological Methods for Artefact Characterization with Robotics Technology. PhD Thesis. ETH Zurich.

Pfleging, J., Stücheli, M., Iovita, R. \& Buchli, J. (2015). Dynamic monitoring reveals motor task characteristics in Prehistoric technical gestures. PLOS ONE 10, e0134570. https://doi.org/10.1371/journal. pone. 0134570

Pfleging, J., Iovita, R. \& Buchli, J. (2019). Influence of force and duration on stone tool wear: results from experiments with a force-controlled robot. Archaeological and Anthropological Sciences 11, 5921-5935. https://doi.org/10.1007/s12520-018-0729-0 
Antony Borel et al. $\bullet$ Qualitative and Quantitative Analyses of Surface Alterations of Stone Tools

Pichon, F., Ibáñez-Estevez, J. J., Anderson, P. C., Douché, C. \& Coqueugniot, É. (2021). Harvesting cereals at Dja'de el-Mughara in the northern Levant: New results through microtexture analysis of Early PPNB sickle gloss (11th millennium cal BP). Journal of Archaeological Science: Reports 36, 102807. doi: https:// doi.org/10.1016/j.jasrep.2021.102807

Qiu, X. (2016). Robotic system allowing the creation of reference traces corpus for the interpretation of the use of prehistoric stone tools (MA thesis). Université Pierre \& Marie Curie, Muséum National d'Histoire Naturelle, Paris.

Rodriguez, A., Yanamandra, K., Witek, L., Wang, Z., Behera, R. K. \& Iovita, R. (2021). The effect of worked material hardness on stone tool wear. OSF Preprints. https://doi.org/10.31219/osf.io/uhkbr

Rots, V., Pirnay, L., Pirson, Ph. \& Baudoux, O. (2006). Blind tests shed light on possibilities and limitations for identifying stone tool prehension and hafting. Journal of Archaeological Science 33, 935-952. https:// doi.org/10.1016/j.jas.2005.10.018

Semenov, S. A. (1964). Prehistoric Technology: An experimental study of the oldest tools and artefacts from traces of manufacture and wear. London: Bath, Adams \& Dart.

Semenov, S. A. (1970). The forms and functions of the oldest tools. Quartär 21, 1-20.

Semenov, S. A. \& Shchelinsky, V. E. (1971). Micrometric study of working traces on the Palaeolithic tools. Sovetskaya arkheologiya 1, 19-30.

Stemp, W.J ., Watson, A. S. \& Evans, A. A. (2015). Surface analysis of stone and bone tools. Surface Topography: Metrology and Properties 4, 013001. https://doi.org/10/gft6dz

Stemp, W. J., Lerner, H. J. \& Kristant, E. H. (2018). Testing Area-Scale Fractal Complexity (Asfc) and Laser Scanning Confocal Microscopy (LSCM) to document and discriminate microwear on experimental quartzite scrapers. Archaeometry 60, 660-677. https://doi.org/10.1111/arcm.12335

Tixier, J. (1963). Typologie de l'épipaléolithique du Maghreb, Mémoires du Centre de Recherches anthropologiques, préhistoriques et ethnographiques Alger. Arts et métiers graphiques, Paris.

Tixier, J. (1982). Techniques de débitage: osons ne plus affirmer. In: Tailler! Pourquoi Faire: Préhistoire et Technologie Lithique II. Recent Progress in Microwear Studies (pp. 13-22). Studia Praehistorica Belgica. Tervuren: Musée Royal de l'Afrique centrale.

Tomenchuk, J. (1983). Predicting the past: examples from the use-wear study of selected chipped stone tools, from two epipalaeolithic occupations in Israël. In: Traces d'utilisation sur les outils néolithiques du Proche Orient. Table ronde CNRS tenue à Lyon du 8 au 10 juin 1982 (pp. 57-76). Lyon : Maison de l'Orient et de la Méditerranée Jean Pouilloux.

Tomenchuk, J. (1988). Effects of loading rate on the reliability of engineering use-wear models. In: Beyries, S. (ed.), Industries Lithiques: Tracéologie et Technologie, Vol. 2 (pp. 99-113). BAR International Series. Oxford: Archaeopress. 